\title{
Robin George Collingwood'un Tarih Tasarımı: Tarih Felsefesi ve Tarihyazımı Süreçleri Üzerine Bir Tartışma
}

\author{
Robin George Collingwood's Idea of History: A Debate Over Philosophy of \\ History and History Writing Processes
}

\author{
Yrd. Doç. Dr. Utku Yapıcı - Yrd. Doç. Dr. Merve Irem Yapıcı
}

\begin{abstract}
Öz
Tarihyazımında nesnellik ve tarih yazıcısının geçmişin bilgisine ulaşılması / tarihin yeniden inşasındaki rolü konuları, tarih felsefesinin en tartışmalı konu başlıkları arasında olmayı sürdürmektedir. Bu çalışmada tarih alanının iki tartışmalı konu başlı̆̆ hakkında İngiliz İdealizminin önemli tarih felsefecileri arasinda gösterilen Collingwood'un ortaya attı̆̆ görüşlerin çözümlenmesi amaçlanmıştır. "Tarihyazımında nesnellik olası midır? Geçmişin bilgisine ulaşabilmek mümkün müdür? Eğer mümkünse hangi yöntemle mümkündür? Tarih yazıcısinin bu noktadaki rolü nedir?" sorularına Collingwood'un verdiği yanitlar tartışılmıştır. Collingwood'un tarihsel imgelem, soru-yant ve yeniden canlandırma kuramları bu bağlamda yorumlanmış, onun tarih-doğa bilimleri farkı üzerindeki vurgusu ve tarihte ilerleme/özgürlük konularındaki görüşleri incelenmiştir.
\end{abstract}

Collingwood, tarihin nesnesi olan olgunun biricikliğini ve kendi başına anlam taşıyıp incelenmeye değer olduğunu savunmuş, tarihçinin yasalar ve genellemelere ulaşma hedefinde değil tekil ve özel olgularla ilgilenme kararlılı̆ıı da olması gerektiğgini vurgulamıştır. Tarihin ancak tarihçi aracıliğıyla ve tarihçinin zihninde yeniden canlandırmaya uğrayarak bugüne taşındığı görüşüne yer vermiştir. Sonuç olarak Collingwood, tarihyazımında nesnelliğin ve geçmişin bilgisine ulaşmanın mümkün olduğunu savunmuş; bu süreçte tarihçinin yaşayabileceği güçlükleri vurgulamış, güçlükleri aşma noktasında tarih yazıcısının başvurabileceği yöntemler önermiştir. Ona göre her tarihçi kendi çağının çocuğu; bir başka ifadeyle kendi çağının değer yargılarının ta- şlyıcısıdır. Ancak eğer kendi döneminin değer yargılarindan arımı tarihte eyleyen aktörün düşünceleri ile kendi düşüncelerini özdeşleştirebilirse geçmişin bilgisine ulaşabilir.

Anahtar Kelimeler: Collingwood, Tarih Felsefesi, Tarihyazımı, İdealizm, Nesnellik

\begin{abstract}
Objectivity in history-writing and the role of historician in reaching the knowledge of past/ reconstruction of history have been among the most disputable subjects of philosophy of history. The basic purpose of this paper is to analyze the idea of Collingwood - who was among one of the most influencial philosophers of history of British Idealism School - about those two controversial subjects of history. Collingwood's answers to the following questions are discussed?: "Is objectivity possible in history-writing? Is it possible to reach the knowledge of past? If yes, then how? What is the role of historician at this point?" Collingwood's historical imagination, question-answer and re-enactment theories are interpreted in this context and his stress on history-natural sciences difference and his views on historical progress/freedom are studied.
\end{abstract}

Collingwood defended unique character of the object of history - fact. He affirmed it as worth reviewing, and emphasized that historician has to deal with unique and particular facts instead of pursuing to reach historical laws and generalizations. He concluded that his-

Yrd. Doç Dr. Utku Yapıcı, Adnan Menderes Üniversitesi Nazilli İİBF Uluslararası İlişkiler Bölümü, uyapici@adu.edu.tr Yrd. Doç Dr. Merve İrem Yapıcı, Adnan Menderes Üniversitesi Nazilli İ̈BF Uluslararası İlişkiler Bölümü, merve.yapici@adu.edu.tr 
tory is transferrred to today merely by historician with re-enactment in the mind of the historician. Consequently, Collingwood stated that objectivity and reaching the knowledge of past are possible. He emphasized the difficulties that the historian has to deal with in this process and proposed some methods that the historian can use in order to overcome those difficulties. According to Collingwood, every historician is the child of his/her own age, in other words a carrier of value judgements of his/her era. However, if he/she could be purified from the value judgements of his/her age and identify his/her idea with the historical actor's mind, it is possible to reach the knowledge of past.

Keywords: Collingwood, Philosophy of History, History-writing, Idealism, Objectivity

\section{Giriş}

$\mathrm{Bu}$ çalıșmanın konusunu İngiliz İdealizmi’nin en önemli tarih felsefecilerinden biri olarak kabul edilen Robin George Collingwood'un ${ }^{1}$ tarih tasarım1nın incelenmesi oluşturmaktadır. Çalışmada bilgide temel olarak düşünceyi alan ve varlığı insan düşüncesinin kurduğu önkabulünde bulunan idealizmin İngiltere özelindeki temsilcilerinden Collingwood'un tarih tasarımı tartışılacaktır. Ancak bunun öncesinde Collingwood'un düşüncesinin oluşma sürecinde

1 Robin George Collingwood, 1889 yllında İngiltere'de dünyaya gelmiştir. On üç yaşına kadar ailesiyle beraber yaşamış ve babası tarafından eğitilmiştir. Collingwood, küçük yaşta sanatla tanışmış, piyano ve keman çalmayı ve resim yapmayı öğrenmiştir. 1912 yllında Oxford Üniversitesi’nden mezun olmuş, Pembroke College'de felsefe ve Roma tarihi üzerine dersler vermiş, arkeoloji alanında çalışmalarda bulunmuştur. İlgisinin neredeyse tümünü din ve teoloji incelemesine yöneltmiştir. $\mathrm{Bu}$ çerçevede 1916 yllında "Religion and Philosophy" (Din ve Felsefe) isimli ilk kitabını çıkartmıștır. Collingwood'un felsefe kariyerini Birinci Dünya Savaşı kesintiye uğratmış, bu savaş sırasında Collingwood, İngiliz Donanma Bakanlığı Haberalma Filosu’nda çalışmıştır. 1930 yılında Collingwood'un sağlığı bozulmaya başlamış, 1938 yılında beyin fonksiyonlarında önemli aksamalara yol açan bir felç geçirmiştir. 1939 yllında ise otobiyografisini kaleme almaya başlamıştır. İngiliz idealizminin temel unsurlarından biri olarak görülen Collingwood 1943 yllında zatürreden ölmüştür (Collingwood, 2001, s. 9-11). Collingwood, felsefenin önemli konuları üzerine bir dizi seçkin kitap yazmıștır. Bunlar, yukarıda aktarılan "Religion and Philosophy"nin dışında "Speculum Mentis" (Zihnin Aynası -1924), "The Principles of Art" (Sanatın İlkeleri - 1938), "The Idea of Nature" (Doğa Tasarımı -1945), "The Idea of History" (Tarih Tasarımı -1946), "An Autobiography" (1939), "The Essay on Metaphysics" (Metafizik Üzerine Bir Deneme -1940). “The New Leviathan" (1942)'dır (Collingwood, 2001, s. 11). Bir Collingwood biyografisi için bkz. (Inglis, 2009). etkisi olan akım ve düşünürlerden söz edilecektir. Böylelikle, Collingwood'un tarih felsefesinin düşünsel arkaplanı gözönüne serilecektir.

Çalışmada Collingwood'un tarih ile ilgili görüşleri yedi başlıkta aktarılmıştır. Bu başlıklardan üçü Collingwood'un tarih tasarımında önemli yere sahip kuramları olan tarihsel imgelem, soru-yant ve yeniden canlandirmadir. Ancak Collingwood'un tarih felsefesinin tam olarak anlaşılmasının, onun tarih ve doğa bilimleri farkı üzerindeki vurgusu, mutlak önkabüller hakkındaki görüşleri, tarihte ilerleme anlayışı ve tarihte özgürlük konusundaki yaklaşımları bilinmeden eksik kalacağı için çalışmaya bu dört başlık da eklenmiştir. Collingwood'un bu konulardaki kuram ve yaklaşımlarına özde onun "Tarih Tasarımı” adlı çalışmasına bağlı kalınarak açıklamalar getirilmiştir². Yeri geldiğinde Collingwood'un diğer makale ve kitaplarına da göndermelerde bulunulmuştur. Okuyucunun dikkate alması gereken nokta, Collingwood'da özellikle tarih-felsefe ilişkisi konusundaki görüşlerinde somutlaşan ve genelde tüm tarih tasarımında da yer yer rastlanan dönüşüm ve tutarsızlıkların bulunduğudur.

Çalışmada cevap aranan temel sorular şunlardır: Collingwood'un tarih tasarımında etkisi olan akımlar ve tarih felsefecileri kimlerdir? Collingwood'un tarih tasarımının özgün olan yanları nelerdir? Collingwood'da tarih-felsefe ilişkisi ne düzeydedir? Collingwood'un tarih yaklaşımında meydana gelen değişimlerin nedenleri nelerdir? Collingwood'un tarih ve bilim hakkındaki görüşleri nelerdir? $\mathrm{Bu}$ görüşler hangi akımlara karşıtlık taşımaktadır? Collingwood'un tarih felsefesine ne gibi özgün katkıları olmuştur?

\section{İngiliz İdealizminin Genel Özellikleri}

İngiliz İdealizmi’nin genel özelliklerini incelemeden önce idealizmin ne olduğu sorusuna cevap vermek gerekir. İdealizm, en basit tanımıyla bilgide temel olarak düşünceyi alan ve varllğ 1 insan düşüncesinin kurduğunu kabul eden öğretilerin genel adıdır (Türk Dil Kurumu Türkçe Sözlük, 1998, s. 1046). İdealizme göre gerçeklik denilen şey temelde zihne bağımlıdır.

\footnotetext{
2 "Tarih Tasarımı" Collingwood tarafindan tarih felsefesi çalışması olarak kaleme alınan bir eser değildir. Çalışma, Collingwood'un ölümünden sonra dersleri, makaleleri ve notlarının derlenmesiyle oluşturulmuştur. Kitabın ilk baskısı, Collingwood'un ölümünden üç yıl sonra kaleme alınmıştır (Bates, 1996, s. 31). Eserin bu nedenle Collingwood'un tarih anlayışını bütünsel bir biçimde değerlendirmekte yetersiz olacağı görüşü için bkz. (Mink, 1968, s. 3-5).
} 
Gerçeklik, idea yani düşünce cinsinden bir şeydir. Tek tek nesneler, onları algılayan ya da onların bilincinde olan bir zihinden bağımsız olarak var olamazlar. Berkeley, Kant, Fichte, Schelling ve Hegel, bu görüşleri bağlamında İngiliz idealistlerinin de düşünsel evrenlerinin oluşma sürecinde önemli etkileri olmuş felsefi öncüllerdir (Aysevener, 2001, s. 10).

İngiliz İdealizmi, 19. yüzyılın ikinci yarısı ve 20 . yüzyılın ilk yıllarında İskoçya ve Oxford'dan tüm İngiltere'ye ve İngilizce konuşan dünyaya yayılan bir felsefi harekettir (British Idealism Guide, Meaning, Facts, Information and Description, http://www.eparanoids.com/b/br/british_idealism_1.html, Boucher ve Vincent, 2000, s. 2). İngiltere'de idealist eğilimin izlerine ilk olarak Fichte, Schelling ve Hegelden etkilenen Samuel Taylor Coleridge'nin şiirlerinde rastlanmaktadır. Bu düşünceyi sistematik bir biçimde işleyen ilk düşünür ise Thomas Carlylédir. Daha sonraları, Benjamin Jowett, Edward Caird, Thomas Hill Grenn, Francis Herbert Bradley, Bernard Bosanquet, Michael Oakeshott ve R.G. Collingwood bu hareketin önemli temsilcileri olmuşlardır (Aysevener, 2001, s. 10).

Yukarıda sayılan İngiliz idealistleri, Kant'tan etkilenerek, deneyci ve olgucuların iddia ettiklerinin tersine "deneyim edinen Ben"in dişında bir olgular ya da nesneler dünyası olmadığını; yani akıldan bağımsız bir dünya olmadığını savunmuşlardır. Bir başka ifadeyle gerçeklik denen şey, İngiliz idealistlerine göre bir bilinçlilik halidir (Aysevener, 2001, s. 14; Boucher, 1994, s. 195). Boucher'in ifade ettiği gibi İngiliz idealizminde akıl, gerçeklerin içine dökülebildiği bir kap olarak değerlendirilmez; aksine aktif bir gerçekliktir. $\mathrm{Bu}$ yaklaşım, kuşkusuz akıldan bağımsız bir dünya olduğu konusundaki empirist ve pozitivist iddianın reddi anlamına gelmektedir (Boucher, 1984, s. 195).

İngiliz idealizminin bir diğer önemli yanı bağlam konusuna yaptığı özel vurgudur. İngiliz idealizmine göre birey, içinde bulunduğu toplumdan ayrı düşünülemez. Hegel'in "her birey zamanının çocuğudur" ifadesi İngiliz idealistlerinin aynen kabul ettikleri bir ifade olmuştur. Bu düşünce akımını savunanlara göre, her düşünce, parçası olduğu bütünle ilişkisi içinde anlaşılabilir. Anlama bağlamla ilişkilidir ve herhangi bir anlama uğraşısı içinde, bulunan düşüncelerin yaratıl1şının ve gelişiminin bilgisi bulunmadan anlama eylemi tam olarak gerçekleşemez (Aysevener, 2001, s. 16).

Collingwood'un kendi çalışmalarında, yazarın İngiliz İdealizmi ile ilgili görüşlerine sıklıkla rastlanmaktadır. Collingwood’a göre İngiliz idealizmi hem negatif hem de pozitif yanlara sahiptir. Negatif yanıyla İngiliz idealizmi pozitivizme bir başkaldırı, aynı zamanda bilime bir saldırı ve bilimsel düşünen akla bir başkaldırı olarak algılanmıştır. Oysa Collingwood’a göre bu düşünce bilime bir saldırı ve akla bir başkaldırı değil, aklı doğa bilimine özgü düşünme türüyle sınırlayan kurama bir başkaldırıydı. Bir şeye başkaldırı, her zaman başka bir şeyden yana bir başkaldırı olduğundan, bu düşünce akımı pozitif yanıyla, doğa biliminden farklı hatta kendi içinde geçerli bir bilgi biçimi olarak tarihin hakkını koruma girişimiydi (Collingwood, 1996, s. 171).

Collingwood’a göre, kendisinin de düşünsel platformunu oluşturan İngiliz idealizmi 19. yüzyılda henüz yeterli bir düzeyde olamamıștır. Bunun nedenlerinden birincisi 19. yüzyıl İngiliz idealistlerinin de pozitivist bakış açısından kendilerini tam olarak kurtaramamaları ile (Collingwood, 1996, s. 171), ikincisi ise tarihsel bir bakış açısına tam olarak sahip olmamaları ile ilgilidir. Bradley, Grenn ve Caird'de tarihsel bakış açısının izleri vardır, ancak bu izler çok belirgin değildir. Bosanquet'te ise, tarihsel bakış açısının izleri tamamen kaybolmuştur (Boucher, 2003, s. 136). Bu bağlamda Collingwood, İngiliz idealizminin tarihsel bakış açısı konusundaki eksikliklerini giderme yolunda çalışmalara girişmiştir. Ancak, yine Collingwood'a göre İngiliz idealizminin içinden tarihsel bakış açısı konusundaki eksiklikleri giderme yönünde önemli adımlar da atılmıştır. Örneğin ona göre, Oakeshott'un "Experience and Its Modes" adlı yapitının tarihle ilgili bölümü "tarihsel düşüncenin gelmiş geçmiş en derin çözümlemesi”dir (Boucher, 2003, s. 135-136).

Collingwood'un Oakeshott'a ilgisi, sonuçlarını tarih tasarımı konusunda vermiştir. Oakeshott ile Collingwood'un tarih tasarımları arasındaki büyük paralellikler dikkat çekmektedir. Bu nedenle, Collingwood'un tarih tasarımını derinlemesine incelemeden önce Oakeshott'a da deyinmekte yarar vardır. Öncelikle her ikisine göre de tarih, diğer herhangi bir kip gibi, kendi nesnesinin; yani tarihsel geçmişin yaratıcı gücüdür. Oakeshott'un ünlü benzetmesiyle; "böcekbilimini nasıl böcekler oluşturmuyor da böcekbilimciler oluşturuyorsa, tarihi de tarihçiler oluşturur" (Boucher, 2003, s. 140). Bu demek oluyor ki, tarihi siyasetçiler, askerler yahut sokaktaki insanlar değil tarihçiler yaratmıştır (Boucher, 1984, s. 196). Yani tarih, tarihçinin şimdiki zamana ilişkin güncel arzuları, hırsları ve sorunlarıyla sıkı sıkıya bağlı bir etkinliktir (Aysevener, 2001, s. 18). Collingwood ile Oakeshott'un görüşlerinin paralelliği tarihin ne olduğu sorusuna verdikleri cevapta da görülmektedir. 
Gerek Oakeshott’a gerekse Collingwood'a göre tarih, ne tarihi yöneten yasaların neler olduklarını açığa çıkarma girişimi ne de insan varoluşunun yapısını ya da planını keşfetmektir. Tarih bir anlama kipidir; yani henüz çözülememiş insan etkinliklerinin tümü hakkında koşulsal ilişkileri anlaşılır kılmanın bir yoludur (Aysevener, 2001, s. 17).

\section{Collingwood'da Tarih-Felsefe İlişkisi}

Collingwood felsefeyi "esas mesleği" olarak sunan, arkeoloji ve tarih alanındaki çalışmalarını ise "amatörce" kabul eden bir düşünürdür (Van Der Dussen, 2012, s. 1). Felsefeyi "esas mesleği" olarak gören Collingwood’a göre, bu meslekle uğraşmak kendine dönük düşünmek anlamına gelmektedir. Felsefe yapan bir zihin, hiçbir zaman yalnızca bir nesne hakkında düşünmemekte, herhangi bir nesneyi düşünürken, o nesne hakkındaki kendi düşüncesi hakkında da düşünmektedir. Bu demek oluyor ki felsefe ikinci dereceden düşüncedir, yani düşünce hakkında düşünce. Psikoloji ise birinci dereceden düşüncedir. Psikoloji, düşünce ile nesnesi arasındaki ilişkiyle ilgilenmemekte, sırf düşünceye odaklanmaktadır. Oysa felsefe hep düşünceyle nesnesi arasındaki ilişkiye bakmaktadır (Collingwood, 1996, s. 31-32).

Bir tarihçiyi, bir filozof ve bir psikologun ele alış şekilleri birbirinden farklıdır. Psikolog tarihçinin düşüncesiyle ilgilenir, onun nesnesiyle değil. Oysa filozof için dikkat isteyen olgu, ne tarihçi için olduğu gibi sadece geçmiştir, ne de psikolog için olduğu gibi tarihçinin geçmiş hakkındaki düşüncesi. Karşıllıklı ilişkileri içinde bunların her ikisidir (Collingwood, 1996, s. 32-33).

Felsefeci ve tarihçiyi yukarıdaki biçimde tanımlayan Collingwood, felsefe ve tarihi bir bütünün parçaları olarak görüp, aralarında ilişki kurmaya çalışmıştır. Collingwood'un felsefeden beklediği, bu bağlamda tıpkı bilimin doğayı açıklaması gibi, felsefenin de tarihi anlaması ve açıklamasıdır (Aysevener, 2001, s. 21, 23). Tarih felsefesi de ona göre, "tarihsel düşünmenin incelenmesi"dir. Bu demek oluyor ki, Collingwood'un tarih felsefesi Hogan'ın ifade ettiği gibi tarihsel yasaları, dünya görüşlerini, döngüleri ya da geleceğe yönelik kurguları değil, daha çok Bradley, Dilthey ve Croce'de olduğu gibi tarihsel bilmenin nasıl olanaklı olduğuna ilişkin bir epistemolojiyi içermektedir (Aysevener, 2001, s. 23). Debbins de, Hogan ile benzer noktalar üzerinde durmaktadır. Debbins'e göre Collingwood'un tarih felsefesi ne tarihsel olayların oluşu hakkında kafa yormak, ne de gelecekteki olayların öngörüsüne dayalı tarihsel genellemeler formüle etmek ve bu genellemeleri meşrulaştırmaktır. Tarih felsefesi, Collingwood'a göre tarihsel düşünüşün ve tarihsel bilginin kendine özgü doğasını aydınlatmaya ve tarih nedir sorusunu cevaplamaya çalışmaktır (Collingwood, 2001, s. 12).

Collingwood'un tarih-felsefe ilişkisi hakkındaki görüşleri temelde yukarıdaki çerçeveye otursa da, onun yapıtlarında bu ilişki konusunda çelişkilerin bulunduğu da göze çarpmaktadır. Boucher, Collingwood'un mantıksal pozitivizme yoğun eleştiriler getirdiği "Tarih Tasarımı" adlı yapıtında, Collingwood'un bununla yetinmediği ve kuram ile pratik arasında ayrım yapan her türlü filozofu yahut felsefi akımı da eleştirdiği görüşünü savunmaktadır (Boucher, 2000, s. 330). Oysa Collingwood, ilk yapitlarında felsefe-tarih özdeşliğini kabul etmemiş, felsefenin tarihten özerkliğini savunmuştur. Hatta bu yapıtlarında Croce’nun felsefe-tarih özdeşliğini savunan görüşlerini reddetmiştir. Ancak daha sonra, Croce'nin savunduğu noktaya gelmiş ve idealizme daha sıkı yöneldikçe tarih ve felsefeyi tıpkı Croce gibi daha fazla özdeşleştirme yoluna girmiştir ${ }^{3}$ (Aysevener, 2001, s. 32). Bu özdeşleştirmeye göre felsefe tarih olmaksızın, tarih de felsefe olmaksızın olanaksızdır. Gerçek bir anlama için tarih felsefeyi, olgular içinse felsefe tarihi gerekser (Aysevener, 2001, s. 34).

Ancak Collingwood, tarih felsefesi alanındaki görüşlerini tarih alanına uygulama konusunda başarısız olmuştur. Evans'a göre Collingwood tarih ve felsefe alanlarının ikisinde de eşit düzeyde başarılıdır. Nitekim Collingwood tarih alanında Oxford Roma Britanyası Tarihi (Oxford History of Roman Britain) ve felsefe alanında Tarih Tasarımı (The Idea of History) adlı çalışmaların yaratıcısıdır. Ancak iki kitabın birbirine yakın durduğuna ilişkin bir işaret yoktur (Evans, 1999, s. 18). Dolayısıyla Collingwood, tarih ve felsefe alanlarında ayrı ayrı başarılı görülse bile, felsefi düşüncelerini tarihsel uygulamalara aktarma konusunda yeterince başarılı olamamıştır. Kurduğu felsefe-tarih ilişkisini uygulama düzlemine aktaramamıştır.

3 Collingwood'un sanat anlayışının da esin kaynağının Croce’nin estetik kuramı olduğu ifade edilmektedir. Hatta bazı yazarlar, Croce ve Collingwood'un sanat kuramlarını yekpare bir kuram olarak sunmaktadır. Bkz. (Kemp, 2003, s. 171). Croce ve Collingwood'un sanat felsefesi konusundaki yaklaşımlardaki benzerlik ve farklı yönleri inceleyen bir çalışma için bkz. (Pavo, 2010, ss. 79-93). 


\section{Collingwood'un Tarih ile Illgili Görüşleri}

Collingwood'un tarih ile ilgili görüşlerinin özü, tarihte olguların başı çektiği ve özerkliği kuramına karşıtlıktır. Bu çerçevede, İngiliz idealizminin genelinde olduğu gibi Collingwood'da da Alman idealizminin etkileri görülmektedir. Collingwood'un tarih görüşü üzerinde etkisi olan düşünürlerin en önemlisi ise İtalyan Croce olmuştur. Croce'un görüşleri, Carr'ın deyimiyle "Birinci Dünya Savaşı’ndan sonra olguların bize 1914 yıllarına oranla daha az lütufkâr bir biçimde gülümser gözükmesinden ve bu nedenle, bizim onların saygınlığını azaltmaya yönelen bir felsefeye karşı daha açik oluşumuz" nedeniyle 1920'lerde Fransa ve İngiltere'de tutunur olmuştu. Collingwood üzerinde de Croce'un bu görüşlerinin etkisi vardı. Croce ayrıca tarihçinin başlica işinin kaydetmek değil, değerlendirmek olduğu ve bunun için de doğa bilimlerinden farklı bir yol izlemesi gerektiği konusunda da (Carr, 2002, s. 24-25) Collingwood’a örnek oldu.

$\mathrm{Bu}$ bölümde, Collingwood'un tarih ile ilgili görüşleri aktarılırken, tarih tasarımının oluşmasında önemli yerleri olan temel kavramlar üzerinde durulacaktır. Bu kavramlar "insan doğası-insanın tarihi”, "tarihsel imgelem", "soru ve yanıt", "yeniden canlandırma" ve "mutlak önkabül” kavramlarıdır. Ayrıca Collingwood'un "tarihte ilerleme" ve "özgürlük" konularındaki görüşlerine de yer verilecek, böylelikle Collingwood'un görüşlerinin bütünsel bir sentezine ulaşma yolu aranacaktır.

\section{Tarih-Doğa Bilimi Farkları Bağlamında Anlama ve Amaçlılık}

Colingwood’a göre tarih ile doğa bilimi arasında farklar oldukça belirgindir. Ancak son tahlilde doğanın bilgisine ulaşmak mümkün olduğu gibi tarihsel bilgiye de ulaşmak mümkündür. Bu demek oluyor ki, tarihin de doğa bilimleri gibi bir bilim olduğu düşüncesi Collingwood'da yer etmiştir (Van Der Dussen, 2012, s. 6). Bu bağlamda Collingwood, tarihin bilgisine erişim konusunda bir yöntem açlımı geliştirmeye çalışmıştır.

Collingwood, Herder'den itibaren süregelen ve aydınlanmanın rasyonalist-mekanist bilim anlayışına karşı, tarih biliminin anlama gibi özerk yöntemlerle çalışması gerektiği düşüncesinin (Özlem, 1992, s. 57) bir ardılıdır. Tarihçi, başka herhangi bir yere varabilmek için öncelikle kaynakları yaratanların zihinsel dünyalarına erişmek zorundadır (Tosh, 1997, s. 130). Bütün tarih aslında aklın tarihidir. İnsanların zihinlerinde olan şeylerin tarihidir (Jenkins, 1997, s. 55-56). Bütün tarihin aklın tarihi olduğu sayıltısıyla hare- ket eden Collingwood, "aklın tarihinin" doğa bilimi yöntemleriyle bilinemeyeceği sonucuna ulaşır. $\mathrm{Bu}$ bağlamda Collingwood'cu anlamda bilimsellik, artık doğa bilimleri anlamında bir bilimsellik değildir. Tarih alanında doğa bilimlerini taklit ederek bilimsel olunmaz (Johnson, 2013, s. xiv-xv).

Onun bilimsel tarih olarak adlandırdığ tarih, doğa bilimlerindeki nedenselliğe değil ancak amaçlıllğ̆a dayalı bir tarih anlayışıdır. Böylelikle Collingwood, hem Comte'un hem de Marx'in tarih tasarımlarina karşı çımış, bu tasarımların içerdiği nedensellik ve nesnellik anlayışlarını reddetmiştir. Hatta böylesi tarih tasarımlarını "sahte tarih" olarak nitelemiștir (Aysevener ve Barutça, 2003, s. 108-109). Onun "insan doğası bilimi” olarak nitelediği, ilkeleri doğa bilimlerinde kullanılanlara benzetilerek tasarlanan bir tarih bilimi anlayışı, Collingwood’a göre işte bu nedenle, yani yönteminin doğa biliminin yöntemine benzetilip çarpıtıldığı için işlememektedir (Collingwood, 1996, s. 248, 250). Collingwood'un önerisi ise doğa bilimlerini de kapsayacak bir öneri değildir. Collingwood, doğaya uygulanan doğa bilimleri yönteminin geçersiz bir yöntem olduğunu da iddia etmemektedir. Collingwood’a göre doğayı araştırmada doğa bilimi yöntemleri uygulanmalı, ancak zihni araştırmada tarihin yöntemleri uygulanmalıdır (Collingwood, 1996, s. 252).

Bu çerçevede Collingwood, her şeyin tarihselliğini ileri süren aşırı düşüncelerin aksine, tarihsel bilginin kendi alanının da sınırlarını çizmektedir. Collingwood’a göre, evrim öğretisinin ortaya çıkması doğal süreç ile tarihsel süreç arasıdaki ayrımı yok etmemiştir. Collingwood'a göre bunun nedeni, doğa durumunda bir olayın içi ile dışı arasında ayrımın görülememesi, yani olayların salt olaylar olmasıdır. Oysa tarihsel alanda, olayların iç ve dış yanları arasında ayrım yapılabilmektedir. Olayın dış yanı, örneğin Sezar’ın bir tarihte kanının senato binasına dökülmesidir. Olayın içi ise ancak düşünce aracilığıla betimlenebilecek bir şeydir. Örneğin, Sezar'ın Cumhuriyet yasasına karş1 çıkması ya da anayasa siyaseti konusunda kendisi ile katilleri arasındaki uyuşmazlıktır. Tarihçi salt olayla, yani olayın dış boyutuyla değil, olayın hem dış hem iç yanlarıyla (Collingwood buna eylem diyor) ilgilenmelidir (Collingwood, 1996, s. 256) ki aslında tarihçi ile doğa bilimci arasındaki temel fark da budur. Bir başka ifadeyle tarihçi ile doğa bilimcinin nesnelerinin yapısı birbirinden farklıdır. Doğal olarak da bu nesnelerin incelenmesinde izlenecek yöntemler de birbirinden farklı olmak zorundadır. 
Tarihçinin, doğa bilimciye kıyasla incelemesi gereken bir iç ve bir de dış yan olması nedeniyle tarihçinin işi Collingwood'a göre doğa bilimciye göre daha karmaşıktır. Tarihçinin bu bağlamda yapacağı en büyük hata doğa bilimciye öykünmektir. Çünkü tarihçi için keşfedilecek şey, doğa bilimcinin aksine salt olay değil, onda dile getirilen düşüncedir. O düşünceyi keşfetmek ise zaten onu anlamaktır. Tarihçi ne olup bittiğini bilirse, neden olup bittiğini de bilir. Dolay1sıyla Collingwood’a göre tarihçinin, anlama sürecinin bir sonrası nedenselliğin bulunması süreci değildir. Anlama, zaten nedenselliği de kapsar. Çünkü olayın nedeni, eylemi olayın olmasına yol açan kişinin zihnindeki düşüncedir; bu da olaydan başka bir şey değildir. Bu demek oluyor ki, tarihçinin aradığ 1 düşünce süreçleridir. Her tarih bir düşünce tarihidir (Collingwood, 1996, s. 257). Tarihçi de her olayla değil, düşüncelerin dışsal ifadeleri olan olaylarla ilgilenir (Collingwood, 1996, s. 260). Böylelikle tarihsel inceleme alanı, düşüncelerin dışsal ifadeleri olan olaylarla sinırlandırılmıştır.

\section{Tarihsel İmgelem}

Tarihçinin ilk görevinin her olayın dışsal yanından hareket ederek olayın iç yanını belirleyip, geçmişin bütünsel resmini yapmak olduğu görüşü bir önceki bölümde aktarılmıştı. Tarihçinin geçmişe ilişkin bu bütünsel resmi nasıl yapacağı da Collingwood tarafından tarihsel imgelem kuramı çerçevesinde aktarılmıştır (Aysevener, 2001, s. 45)

Collingwood, tarihsel imgelem kuramını açıklarken, hemen tüm kuramlarında yaptı̆̆ 1 gibi kendisinden önceki dönemlerin tarih yazıcıllı̆ının saptadığı eksikliklerinden yola çıkmıştır. Yazar, ilk iş olarak "ortak duyu kuramı"nın tarihteki en önemli şeyin anı ve yetke olduğu şeklindeki sayıltısını çürütmeye çalışmıştır. $\mathrm{Bu}$ anlayışa göre tarih, başka biri bir şeyi anımsadığı zaman ona inanmaktır. İnanan tarihçi, inanılan ise onun yetkesidir. Bunun bir adım ötesi, yetkelerin söylediğini eleştirel bir biçimde değerlendirmek, kabul yahut reddetmektir. Oysa Collingwood'a göre tarihçi, yetkelerin kendisine anlattı̆̆ 1 şeyin ötesine geçmelidir (Collingwood, 1996, s. 275-284). Bu ise boşlukları doldurma ile mümkündür. Tarihçi, geçmişe ilişkin resmi ancak boşlukları doldurma ile yapabilir. Tarihçi, kendi yetkesinin ona sunduğu unsurlarla oluşturulmuş olan resimdeki boşlukları "bütünleme" işlemi ile doldurur. Dolayısıyla tarih, bir bütünleme işlemi ile tarihçi tarafından kurulmaktadır. Ancak bu durum, yani tarihçi tarafından kurulan geçmişin bir imgelem çalışması olduğunu söylemek, onun tıpkı bir roman gibi, kurgu olduğunu söylemek değildir (Aysevener, 2001, s. 46-47) Çünkü bütünleme eyleminin şu iki olmazsa olmaz özelliği onu kurgudan ayırmaktadır: (1) Bütünleme eylemi hiçbir biçimde isteğe bağlı yapılamaz. Kesinlikle zorunludur. (2) Çıkarsanan şey imgelenmiş bir şeydir. Collingwood, bu iki özelliği kapsayan etkinliğe a priori imgeleme adını vermektedir (Aysevener, 2001, s. 48). Collingwood'a göre, yetkelerin anlattıkları arasındaki yarıklara köprü kuran ve tarihsel anlatıya sürekliliğini veren bu etkinliktir (Collingwood, 1996, s. 285). Tarihsel imgelem olmaksızın, tarihçinin söyleyeceği hiçbir şey yoktur. İmgelem, kendisi olmaksızın çevremizi algılayamayacağımız bir tür vazgeçilmez kavramsal çerçevedir.

Burada önemli olan noktalardan biri de, a priori imgeleme yöntemini kullanırken, araştırmanın eleştirel boyutunu gözden kaçırmamaktır. Çünkü tarihçi gerçeğe, yetkelerin ona anlattığını sorgusuz sualsiz kabul ederek değil, onu eleştirerek ulaşabilir. Tarihsel imgelemin aralarına ağını ördüğü varsayımsal sabit noktalar ise tarihçiye hazır olarak verilmezler. O noktaların da eleştirel düşünmeyle elde edilmeleri gerekir. (Collingwood, 1996, s. 287).

Sonuçta, tarihçinin yukarıdaki yöntemle çizdiği resim, romancının çizdiği resimden farklı olur. Çünkü tarihçi çizdiği resmin doğru olduğunu iddia etmektedir. Romancı ise sadece tutarlı ve anlamlı bir resim kurmakla uğraşmaktadır. Tarihte hakikate ilişkin ölçüt de, tarihçinin çizdiği tarih tasarımının kendisi olmaktadır (Collingwood, 1996, s. 290, 293).

\section{Soru ve Yanit}

Collingwood, An Autobiography isimli eserinde, soru-yanıt mantığı ile ilgili geliştirdiği kuramın çıkış noktasının arkeoloji alanında yapmış olduğu saha çalışmaları olduğunu ifade etmektedir. Collingwood’un şu sözleri arkeolojik çalışmalarının onun geliştirdiği tarih felsefesi üzerindeki etkileri açıkça ortaya koymaktadır:

"Kazı çalışmalarındaki uzun deneyimim bana şunu öğretti. Sahada başarının bir koşulu - doğrusunu söylemek gerekirse en önemli koşulu - şudur: Kazının herhangi bir parçasından sorumlu olan bir kişi bu küçük bir parça da olsa - tam olarak neden bunu yaptığını bilmek durumundadır. O her şeyden önce ne bulmak istediğine, hemen ardından da ne çeşit bir kazının ona bulmak istediğini sergiyeleceğine karar vermelidir" (Collingwood, 1939, s. 122'den aktaran Salas, 1987, s. 53). 
Collingwood, soru-yanıt mantığı ile ilgili kuramını, diğer birçok kuramında olduğu gibi, yanlıș olduğunu düşündüğü yöntemlerden hareket ederek geliştirmiştir. Collingwood'un tanımlamasına göre, tamamen yetkelerin tanıklığına dayanan ve farklı yetkelerin tanıklıklarının seçilip birleştirilmesi yoluyla kurulan tarihe makas-zamk tarihi adı verilmektedir. 17. yüzyıla kadar temel tarih anlayışı budur. Bu yüzyıldan başlayarak eleştirel tarih gelişmeye başlamıştır. Ancak Collingwood'a göre eleştirel tarih de makas-zamk tarihçiliğinin bir türevi olmaktan öteye geçememektedir. Çünkü bu değişim, tanıklıkları karalar ve aklar şeklinde ikiye ayırma tekniğinden başka bir şey değildir (Collingwood, 1996, s. 294-315).

Collingwood’a göre, eğer bir tarihçi hazır verilmiş ifadelerle yetinir ve bu ifadeleri kendi tarihsel bilgisinin bir parçası olarak yeniden ileri sürerse yaptığ 1 iş bir makas-zamk tarihçiliği olur ki bu bilimsel bir tarihçilik değildir. Ona göre tarihsel bir araştırmada, bir metni anlaşılır kılacak tek yol, tarihçinin metnin yanıtladığı soruyu bulmasıyla şekillenir. Eğer bir tarihçi, tarihsel verileri iyi değerlendirir ve uygun soruları kurabilirse, geçmişte olanlar hakkında daha tutarlı ve doğru açıklamalara ulaşabilir. Bu yönüyle soru ve yanit mantığı, tarihsel anlama ya da bilmenin felsefi bir sorgulamayla gerçekleşebileceğini savlayan bir tarih yöntemidir denilebilir (Aysevener, 2001, s. 67, Goldstein, 1970, s. 6). Collingwood'un soru-yanit mant1ğına göre, hiçbir önerme salt kendisi olarak bir anlam ifade etmemekte, her önerme karşıllğı olan soru ile bir anlam kazanmaktadır. Bir başka ifadeyle, belli bir soruyla ilişkili olmadıkça hiçbir şey kanıt değildir. Bu da araştırmacının, tarihe yönelirken kendisini ilerletecek uygun soruları sormasını gerekli kılar ve işte bu sorular, konunun altında yatan düşünsel zeminin bulunmasında ona yardımcı olur (Aysevener ve Barutça, 2003, s. 109-110). Bu açılım sayesinde Collingwood’a göre kör ve rastlantısal bir çalışma, kesin soruların sorulduğu ve kesin yanıtlarda israrcı olunduğu bir biçime dönüștürülmüş olur (Collingwood, 1939, s. 122'den aktaran Salas, 1987, s. 53).

Collingwood, "Tarih Tasarımı" adlı yapitında, soruyanıt mantığını bazı örneklerle aktarmış, bu örneklerde makas-zamk tarihçisi ile bilimsel tarihçi modellerinin olası tavırları arasındaki farklılıkları sergilemiştir. Örneğin, Tukudides'in bir kitabını makas-zamk tarihçisi, bu yazarın söylediği şeyleri sadece ve sadece bulup çıkartmak için alıcı bir ruhla okurken, bir bilimsel tarihçi öncelikle ondan bulup çıarmak istediği șeyleri kendisine sorarak; yani zihninde bir soruyla araştır- masina koyulur (Collingwood, 1996, s. 315). Makaszamk tarihçisi için tarih, başka insanların ondan önce verdikleri ifadeleri yenilemek demekken, bilimsel tarihte hiçbir hazır ifade bulunmaz. Bilimsel tarihçi incelediği konuyla ilgili hazır bir ifadeyle karşılaştığında "Bu ifade doğru mu yoksa yanlış mı?" diye de kendi kendine sormaz. Sorduğu soru, "bu ifadenin anlamı nedir?" olur. Bu soru da "Bu kişinin, her ne söylüyor olursa olsun, bu ifadeyi vermiş olması, ilgilendiğim konuya nasıl bir $1 s ̧ 1 \mathrm{k}$ tutuyor?” sorusuyla eşdeğerdir. Bu demek oluyor ki, makas-zamk tarihçisi ifadelerin içeriğiyle, yani dile getirdiği ile ilgilenirken bilimsel tarihçi dile getirilmiş olmalarıyla ilgilenir (Collingwood, 1996, s. 321). Anlamın gerçekten bağımsızlığı fikrini merkeze alan bir eleştiri sunar. Yetkelerin verdiği ifadeleri inanılmaz bulsa da, onları anlamaya odaklanır. Örneğin, Collingwood'un yaklaşımına göre tarihçi, mucizevi olayların varlığı konusundaki bir yetke ifadesini, gerçeklik konusundaki kendi gözlemlerine dayanarak "yanlış" olarak tanımlayıp araştırma dışı bırakmamalıdır (Doro, 2004, s. 202). İfadenin verilmiş olmasından yola çıkarak, yetkenin düşüncesini; zihnindeki gerçekliğini keşfetmelidir.

Collingwood'un soru-yanlış mantığı ile ilgili kuramı, sorulan soruların araştırmanın nesnelliğini bozucu etkilerine odaklanan birçok eleştiri ile karşılaşmıştır. Örneğin, E. B. Birley, Collingwood'u rehber alan bir yaklaşımla yapılacak araştırmaların bulmayı umduğu şeyi, gerçekte o orada yoksa bile bulma eğiliminde olacağını ifade etmiştir. I. A. Richmond ise "kazıcının" birinci görevinin, görüş alanını engelleyecek önceden hazırlanmış bir misyona ait at gözlüğünü takmamak; bir başka ifadeyle görüş alanını engellememek olduğunu ifade etmiştir. Richmond, tarihçinin her şeyi görmek zorunda olduğunu vurgulayarak Collingwood'un yaklaşımını, sorulan soruların gerçeği görmede bir zafiyet oluşturacağ 1 vurgusuyla eleștirmiștir (Salas, 1987, s. 54).

\section{Yeniden Canlandırma}

Collingwood'un idealist görüşleri doğrultusunda oluşturduğu tarih felsefesinin bir diğer savı 1928 y1lında geliştirdiği geçmişteki düşüncelerin yeniden canlandırılmasına ilişkin olan savdır (Dray, 1995, s. 33). Bu sav, Dray'e göre sadece Collingwood'un tarih felsefesinin merkezini oluşturmakla kalmamakta, onun görüşleri arasında en tartışmalısı olmaktadır (Dray, 1980, s. 1).

Collingwood'un yeniden canlandırma savının merkezinde geçmişteki bir düşüncenin aslına uygun 
olarak yeniden canlandırılmasının olanaklı olduğu düşüncesi yer alır. Ona göre bu durum bilimsel tarihin bir önkabulüdür (Aysevener, 2001, s. 69). Yeniden canlandırma, Collingwood'a göre şöyle işlemektedir: Tarihsel olarak düşündüğünde, bir kimsenin önünde geçmişe ilişkin birtakım belgeler ya da kalıntılar vardır. Onun yapması gereken bu kalıntıları bırakmış olan geçmişin ne olduğunu keşfetmektir. Kalıntıların birtakım yazılı sözcükler olduğu durumda, sözleri yazmış kişinin bu sözlerle ne demek istediğini keşfetmesi gerekmektedir. Bu da o kişinin sözcüklerle dile getirdiği düşünceyi keşfetmek demektir. Bu düşünceyi keşfetmek için de, tarihçi bunu yeniden kendi kendine düşünmelidir (Collingwood, 1996, s. 329).

Bir başkasının, geçmişteki bir başka zaman dilimi içindeki düşüncesinin yeniden canlandırılabileceği önkabulü, Collingwood'un bir diğer önkabülü olan "düşüncelerin asla yok olmadıkları" fikriyle desteklenmektedir. Düşünceler, asla yok olmadıkları için onların yeniden canlandırılabilmeleri mümkündür. Bir başka deyişle, "tarihçi ile onun nesnesi arasındaki zaman uçurumunun, her iki uçtan da kapatılması" mümkündür ve Collingwood'un da istediği budur (Aysevener, 2001, s. 70).

Collingwood’a göre geçmişte yaşamış birinin düşüncelerinin bilinebilmesi de bazı koşullar altında mümkündür. Bu koşulların ilki, düşüncenin dil ya da başka açılama biçimlerinden biri ile açıklanmış olmasıdır. İkincisi ise doğrudan tarihçiye ilişkin bir koşuldur. Tarihçi, yorumlamaya çalıştı̆̆ı açıklamayı bir zamanlar düşünüldüğü gibi yeniden düşünebilmelidir. $\mathrm{Bu}$ iki koşul gerçekleşince tarihçi bir keşif sürecinin içine girer. Geçmiş de zaten ancak bu keşif süreci ile aydınlatılabilir. Keşif ise düşüncelerin yeniden canlandırılmasıdır (Aysevener, 2001, s. 71). Düşünceler ölmezler, ancak geçmiş düşünceler kendiliklerinden de yaşayamazlar. Onlar yalnızca bir tarihçinin düşünceleri kendi zihninde yeniden canlandırmayı başarabildiği zaman yaşarlar. Bu görüşten hareket eden Collingwood, tarihsel bilgiyi şu şekilde tanımlamıştır: "Tarihsel bilgi, geçmişteki bir düşüncenin, bugünün düşünce bağlamında kapsüllenmiș düşünce biçiminde yeniden ele alınmasıdır" (Aysevener, 2001, s. 72-73).

Collingwood, "yeniden canlandırma" ile ilgili görüşlerinde düşünce ile duygu arasındaki ayrıma da özel vurgu yapmıştır. Ona göre, düşüncelerin aksine, geçmiş duygular, bir daha ele geçmeyecek biçimde yitirilmişlerdir. Geçmişteki duygular yeniden duyulamaz, tekrarlanamazlar (Hopkins, 1965, s. 229). Şimdiki zamanda, yeniden canlandırma ile ortaya çıkarılan dü- şünce, geçmiş düşünceyle aynı olabilir, oysa bu şekilde ortaya çıkartılacak duygular olsa olsa geçmişteki duygulara benzerler. Ancak geçmişteki duyguyu yeniden duyamamak, bu duyguyu düşünememeyi gerektirmez. Örneğin bir insanın geçmişte şiddetli bir biçimde susadığı bir durumu düşünmesi için yeniden susamasına gerek yoktur. Sonuç olarak, Collingwood, duyguların yeniden canlandırılması olasılığını reddetmektedir. Zaten yeniden canlandirma kuramı da, tarihsel temsilcilerin duygularının yeniden yaşanmasinı gerektirmemektedir (Aysevener, 2001, s. 76-77). Bir başka ifadeyle, ona göre tarihin konusunu sadece insan davranışının belirli bazı biçimleri oluşturmaktadır. Dürtüler ve hisler tarafından biçimlendirilen davranışlar kapsam dışıdır (Boucher, 1993, s. 705).

Collingwood'un, düşüncelerin yeniden canland1rılması sürecinde, tarihçi tarafından ortaya atılan düşüncenin geçmişteki düşünceyle aynı olacağını ifade etmesi, "yeniden canlandırma sürecinin" yorumu dışladığının bir göstergesi olarak değerlendirilebilmektedir. Collingwood'un yeniden canlandırma sürecinde yorumun olmadığını ifade etmesi, Collingwood'un bu yolla, tarihte nesnellik sorununa bir çözüm arayışı içinde olduğu şeklinde yorumlara yol açmıştır. Collingwood'da bu noktada bir nesnellik kaygısı görünse de, Carr’a göre Collingwood'un tarihi tarihçinin yaptığ 1 şey olarak gören anlayışı, diğer taraftan her türlü nesnel tarihi imkânsız kılmaktadır. Collingwood ona göre, tarihi insan beyninden dokunmuş bir şey diye ele almaya tehlikeli bir biçimde yaklaşmaktadır. Tarihin bir anlamı olmadığı kuramının yerine anlamların sınırsızlı̆̆ kuramını koymaktadır. Buna göre anlamların hiçbiri diğerinden daha sağlam değildir. Carr’a göre bu anlayış, en az tarihin bir anlamı olmadığ 1 kuramı kadar savunulamayacak niteliktedir. Carr, Collingwood'un nesnel tarihi imkânsız göstermeye yönelik tavrını Collingwood'un şu sözlerine göndermede bulunarak eleştirmiştir: (Carr, 2002, s. 30-31).

\section{"St. Augustine tarihe erken dönem Hıristiyanların görüş açısından bakmıştır. Tillamont bir 17. yüz- yıl Fransizı̉nın, Gibbon bir 18. yüzyıl İngilizỉnin; Mommsen bir 19 yüzyıl Almanı’nın... Hangisinin görüşünün doğru olduğunu sormanın bir anlamı yoktur. Bunların her biri, onu benimseyen kişi için olabilecek bir şeydi" (Carr, 2002, s. 30-31).}

$\mathrm{Bu}$ görüşler Evans’a göre, Einstein’n izafiyet kuramının (1913) Collingwood üzerindeki etkisine dayanmaktadır. İzafiyet kuramının, "şeylerin durumlarının gözlemcinin konumuna göre değiştiğini 
ifade etmesinin" etkisiyle, gözlemcinin ve olgunun göreceliği düşüncesi Collingwood tarafından tarihe de uygulandı (Evans, 1999, s. 37) demektedir Evans. Böylelikle tarihsel kavrayışın göreceliliği konusunda Collingwood'un neredeyse postmodern kuramının onun tarihte nesnelliği olanaklı gören yeniden canlandırma konusundaki yöntemsel çıkışı ile çelişkili olduğu söylenebilmektedir (Bates, 1996, s. 33). Bu görüşlere karşsllık, Collingwood'un yeniden canlandırma kuramının nesnellik bağlamında bir çelişki taşımadığını iddia edenler de vardır. Örneğin Leo Straussa göre, Collingwood'da nesnellik, evrensel geçerlilik olarak tanımlanmamaktadır. Zaten nesnelliğin böyle bir tanımı geçerli kabul edilirse Collingwood'un tarih tasarımının nesnelliğinden söz etmek mümkün değildir. Geçmiş düşüncenin yeniden canlandırılması geçmiş düşüncenin eleştirel bir biçimde yeniden değerlendirilmesiyle özdeştir. Bilimsel tarihçinin geçmiş hakkındaki eleştirel düşünce biçimi ise bugünkü bağlamı tarafından belirlenmektedir. Bu nedenle Strauss'a göre Collingwood'un her neslin kendi tarihini yazacağı konusundaki görüşleri ile yeniden canlandırma kuramı arasında bir çelişki bulunmamaktadir (Strauss, 1952, s. 560-562).

Collingwood'a yeniden canlandırma kavramsallatırması üzerinden yapılan eleştiriler sadece tutarsızlık bağlamında gerçekleştirilmemiştir. Collingwood'un yeniden canlandırmanın olanaklılığını merkeze alan tarih felsefesinin, tarihi bireylerin düşüncelerine indirgemek anlamına geldiğine yönelik eleştiriler de gözlenmektedir. Örneğin Carr, Collingwood'un tarihi bireysel aktörün düşüncesiyle sınırlandırdığını düşünür ve bunu büyük bir hata olarak tanımlar. D. H. Fisher ise tarihçilerin topluluğun düşüncelerini yeniden canlandırmalarını kategorik olarak olanaksız görür. Buradan da Collingwood'un tarihsel yönteminin hem eksik hem yanlış olduğu sonucuna ulaşır (Dray, 1980, s. 2). Collingwood'un bu yöntemsel önermesini yetersiz, tutarsız, akıldışı ve mistik olarak yorumlayıp, felsefi açıdan ciddiye alınmaması gerektiği görüşünü ortaya atan eleştiriler yaygındır (Bates, 1996, s. 34).

\section{Mutlak Önkabüller}

Collingwood, "An Essay on Metaphysics" adlı yapıtında mutlak önkabüller ile ilgili görüsşlerini dile getirmiştir. Collingwood, bu çalışmasında mutlak önkabüller ile göreceli önkabüller arasındaki ayrımı ifade etmek ile işe başlamıştır. Collingwood'a göre göreceli önkabüller doğrulanabilir yahut yanlışlanabilir. Bir başka deyişle, göreceli önkabüller, belirli soruların yanıtları olup, sorgulanabilirler. Oysa mutlak ön- kabüller, hiçbir biçimde herhangi bir sorunun yanıtı olmazlar. Mutlak önkabüller önerme değillerdir. Ne doğrulanabilirler, ne de yanlışlanabilirler (Aysevener, 2001, s. 82-83).

Collingwood mutlak önkabüller ile bilimsel etkinlik arasındaki ilişkiye özel bir vurgu yapmıştır. Ona göre mutlak önkabüller, bilimsel etkinlikte bulunmanın önkoşullarıdır. Onlar olmadan bilim adamlarının yapabilecekleri ve söyleyebilecekleri hiçbir şey yoktur. Bilim adamları mutlak önkabülleri sorgulama yapabilmek için ortaya atmak zorundadır. Baskılar çok arttığında, eğer bu baskılar, mutlak önkabüllerden bazılarının değiştirilmesiyle yahut yadsınmasıyla ortadan kalkmazsa bütün birlik bozulur. Bilim adamları yeni bir birliği benimsemeye zorlanırlar (Aysevener, 2001, s. 85-86). Collingwood'un bu görüşü, Thomas Kuhn'un "The Structure of Scientific Revolutions" (Bilimsel Devrimlerin Yapısı) adlı yapıtında merkezi bir yer edinen paradigma kavramına ilham vermiştir. Tipkı Collingwood'un mutlak önkabül kavramında olduğu gibi Kuhn'un paradigma kavramı da bilimde "oyunun kurallarını" belirleyen değerlerden oluşur (Hughes-Warrington, 2003, s. 91). Gelişmelere cevap veremeyen paradigmalar devrim yoluyla yerini yeni paradigmalara birakır.

Mutlak önkabüller kuramında Collingwood, her türlü bilme etkinliğinde metafiziğin neden göz ardı edilemeyeceğini kanıtlamaya çalışıştır. Zaten Collingwood’a göre metafizik, felsefi bir disiplin değil, tarihsel bir bilimdir. Collingwood'un bu görüşleriyle şekillenen mutlak önkabüller kuramı, Aysevenere göre, ampiristlerin katı bilimci yaklaşımlarına karş1 ses getirmiş bir kuramdır (Aysevener, 2001, s. 81, 88). Johnson'a göre ise Collingwood, metafiziği tarihe yeğlemekten ziyade, tıpkı felsefe-tarih ilişkisinde olduğu gibi metafizik ile tarihi yakın ve yapıcı bir ilişki biçiminde buluşturma gayreti sarf etmiştir (Johnson, 1998, s. 122).

Collingwood'un kendi tarih anlayışındaki mutlak önkabüller ise şunlardır: (1) Tarihsel bir geçmiş vardır: Tarihsel bir geçmişle Collingwood, zaman ve mekân içinde sınırlandırılmış olaylardan oluşan ve kanıtlara dayanan çıkarımlarla doğrulanabilen bir geçmişi kastetmektedir. Belgeler ve kanıtlar yoluyla bize ulaşan, geçmişteki sorunların etkileridir. Bu etkiler sayesinde geçmişin var olduğunu kabul edebiliriz (Aysevener, 2001, s. 91) (2) Tüm tarih düşünce tarihidir. (3) Tüm tarih, geçmiş düşüncenin tarihçinin zihninde yeniden yaratılmasıdır. (4) Tarihçinin incelediği geçmiş düşün- 
celer ölü değillerdir; geçmiş oldukları bilinse de bir bakıma hâlâ şimdiki zamanda yaşarlar (Collingwood'a göre geçmiş düşünceler kendiliklerinden yaşayamazlar; onlar ancak bir tarihçi onları yeniden canlandırmayı başardığı zaman yaşarlar. Collingwood geçmiş düşüncelerin şimdiki zamanda var olduklarını iddia ederken bağlam düşüncesini göz ardı etmiş̧ir. Bu da Collingwood'un önkabulünün en sorunlu yanıdır). (5) Tüm düşünce eleştirel düşüncedir; bunun için geçmiş düşünceleri yeniden yaratan düşünce onları yaratırken eleştirir. (6) Tarihsel gerçekliğin ölçütü a priori imgelemdir. (Tarihsel anlatıları öyküden ayıran temel nokta da budur). (7) Tarihçi ne olduğunu bilirse neden olduğunu zaten bilir. (8) Tarihte olabilirliği değil kesinliği talep ederiz (Aysevener, 2001, s. 90-114).

\section{Tarihte Ilerleme}

Collingwood, ondokuzuncu yüzyılda popüler bir kullanımı olan ilerleme kavramı konusunda da özgün görüşler sunmuştur. Collingwood, bu konudaki görüşlerini ortaya atmaya, tarihte ve doğada ilerleme arasındaki ayrımı vurgulayarak başlamıştır. Evrim sözcügünün kullanımını doğada ilerleme alanıyla s1nırlamış, tarihsel ilerlemenin doğadaki ilerlemeden farklı olduğunu ifade etmiştir. Collingwood’a göre doğa yasasınca belirlenen tarihsel ilerleme anlayışı anlamsızdır, ancak bu anlamsızlık nedeniyle tarihsel ilerlemenin de anlamsız olduğu sonucuna ulaşmak acelecilik olur (Collingwood, 1996, s. 370-373).

Collingwood'a göre tarihsel ilerleme, aynı özgül tiplere giren eylemlerde, düşüncelerde ya da durumlarda meydana gelen değişmeleri ifade etmektedir. Örneğin, bir topluluk yemek ihtiyacını balıkla gidermektedir. Ancak yeterli balıkları kalmadığı zaman, toprağı kazıp kök çıkararak yiyecek aramışır. Bu, özgül durum ve etkinlik tipinde bir değişmedir; dolayısıyla Collingwood'a göre tarihsel ilerleme sayılmaz. Ama balık yiyen topluluğun balık tutma eylemindeki yöntemleri geliştirmesi ve bu yöntemle tuttuğu balık sayısında bir artış oluyorsa, bu durum ona göre bir ilerleme örneği olabilir. (Collingwood, 1996, s. 374).

Collingwood'a göre tarihçinin tarihsel ilerlemenin varlığını saptayabilmek için yapması gerekenler vardır. Öncelikle ilerleme konusunda karşılaştırdığı iki yaşam biçiminin temel özellikleri ve değerleri içine eşit bir biçimde zihinde yeniden canlandırma aracıl1ğıyla girebilmelidir. Tarihçi, bu koşulu yerine getirdiği zaman, ilkinden ikinciye giden değişmenin bir ilerleme olup olmadığını sormaya hak kazanır (Collingwood, 1996, s. 378-379). Ancak tarihçinin yapacağı şey burada bitmez. Bu ilerlemenin kimin açısından gerçekleştiği sorusuna da bir cevap vermelidir. Örneğin, balık tutan bir topluluğun yöntem değişikliği ile az zamanda daha fazla balık tutuyor olması, yarım gün boş kalmak istemeyen bir kişi için ilerleme sayılmayabilir, hatta çöküş olarak yorumlanabilir (Collingwood, 1996, s. 374-375). Ya da Johnson'un ifade ettiği gibi Collingwood'un anlayışıyla, 19. yüzyılda Amerika Birleşik Devletleri’nin güney eyaletlerinde köleliğin yasaklanması moral bir ideale toplumu yaklaştırma bağlamında ilerleme olarak kabul edilebilir ancak birçok köle sahibi için bu dönüşüm bir ıstırap kaynağıdır, gerileme belirtisidir (Johnson, 2013, s. 120).

Yeniden canlandırmayı ilerlemenin saptanmasında bir araç konumuna taşıyan Collingwood, tarihsel ilerleme konusundaki bütünsel yargılara ise cephe alır. Bir anlamda ilerleme kavramı üzerinden yeniden canlandırmanın sinırlılıklarını ortaya koyar. Collingwood'un bu yaklaşımının oluşumunda onun tarih tasarımını biçimlendiren şu görüş etkili olmuştur: Bir dönemin yahut uygarlığın diğerinden üstün olup olmadığının bilinebilmesi için iki dönemin ya da uygarlı̆̆ın bağlamlarının tamamen bilinmesi gerekir. Oysa tarihçinin elinde, dönemin yahut medeniyetin bütüncül bir resmini çizmeye yetecek ölçüde veri bulunmaz (Collingwood, 1996, s. 379). Bir başka ifadeyle tarihçi, nesnesini ancak bölük pörçük görebilir, bu yetersizlik ise ilerlemenin varlığını kanıtlayabilecek bütünsel bir kıyası olanaksız kılar. Collingwood'un her tarihsel olay veya dönemin biricikliği vurgusu da bu noktada önem kazanır. Collingwood’a göre her tarihsel olay veya dönemin biricikliği görüşü, ilerlemenin varlığını kanıtlamak için gerekli olan kıyası olanaksız kılan bir diğer faktöre dönüşür. Çünkü tarihsel olay veya dönemlerin ilerleme çerçevesinde bir kıyasa tabi tutulması, tamamen farklı bağlam ve tarihsel gerçekliklerin de kıyasını gerektirir ki bu Collingwood'un paradigması içinde olanaksızdır (Levesque, 2008, s. 98). Bu bağlamda Collingwood, tarihçinin bir tarihsel dönemin yahut medeniyetin ilerleme çizgisinde konumlanıp konumlanmadığ konusunda "büyük sözler" söylemesini onaylamamaktadır. Oysa Collingwood'un yeniden canlandırma kuramı, diğer taraftan, "büyük sözler" söyleyebilmenin olanaklılığının kabulü anlamına gelmektedir. Çünkü Collingwood, yeniden canlandırılan düşüncenin ilkinin aynı olacağını kabul ederek, aynı önermeyi iki farklı bireyin iki farklı zaman boyutunda farklı kaygılarla okumuş olacaklarını ve dolayısıyla farklı sonuçlar çıkarabileceklerini göz ardı etmektedir (Aysevener, 2001, s. 73). 


\section{Tarih ve Özgürlük}

Collingwood’a göre tarihsel doğacilığın yok oluşu, insanın sürekli değişen tarihsel dünyasını kurma etkinliğinin özgür bir etkinlik olduğu sonucunu beraberinde getirmektedir. Onu denetleyen, değiştiren, şu ya da bu biçimde davranmaya, şu tür değil de bu tür dünya kurmaya zorlayan, kendi etkinliğinin dışında hiçbir güç yoktur. İnsan, durumun zorlamasını kendi aklının etkinliğine yöneltir. Zorunluluk kaynağı olarak görülen durum da aslında onun yaratısıdır (Collingwood, 1996, s. 365-366).

Collingwood, tarih ve özgürlük konusundaki düşüncelerini şu örnekle açılamıştır: Bir insanın dağları aşmasının güç olmasının nedeni, oralardaki cinlerden korkması olabilir. Bu durumda tarihçinin, yüzyıllar ötesinden gelip ona bunun tamamen batıl bir inanç olduğunu, cin diye bir şey olmadığını söylemesinin bir anlamı yoktur. Tarihçi, cinlerin olgu olmad1ğını söyleyebilir, çünkü ona böyle düşünmesi öğretilmiştir. Ama cinden korkan da cinlerin varlı̆̆ının bir olgu olduğunu söyler. Tarihçinin yapması gereken, eylemlerini incelediği insanların bu seçimlerinde özgür olduklarını keşfetmektir. Eylemlerini incelediği insanın özgürlüğünü keșfedince, tarihçi kendi özgürlügünü de keşfeder. Yani tarihsel düşüncenin özerk yapısını, kendi sorunlarını kendi kendine ve kendi yöntemleriyle çözme gücünü keşfeder (Collingwood, 1996, s. 366-367).

\section{Sonuç}

İngiliz idealist tarih anlayışının en önemli temsilcilerinden biri olan R.G. Collingwood'un düşüncelerinin oluşum sürecinde önemli bir pay Hegel, Fichte ve Schelling gibi Alman idealistlerdedir. Özellikle Hegel'in "her bireyin zamanının çocuğu olduğu" şeklindeki görüşü, Collingwood'daki bağlama vurgunun temelini oluşturmaktadır. Collingwood ayrıca, felsefe-tarih özdeşliğini savunan görüşlerinin olgunlaşma sürecinde Croce'den de etkilenmiştir.

Collingwood'un tarih tasarımında felsefe merkezi bir yer işgal etmektedir. Ona göre düşünceyle nesnesi arasındaki ilişkiyi ortaya çıkaran felsefe, tarih için bir vazgeçilmezdir. Onun felsefeden beklediği, tıpkı bilimin doğayı açılaması gibi, felsefenin de tarihi anlaması ve açıklamasıdır. Gerçek bir anlama için tarih felsefeyi gereksemektedir.

Collingwood, tarih ile doğa bilimleri ayrımına hemen her çalışmasında vurgu yapmıştır. Ona göre tarih aslında düşüncenin tarihidir ve düşünce de doğa biliminin yöntemlerini kullanarak bilinemez. Doğa bilimleriyle tarih biliminin nesnelerinin niteliksel farklılıklarından hareket eden Collingwood, tam da bu nedenle doğa bilimlerinin yöntemlerinin tarih bilimine uygulanamayacağı sonucuna ulaşmaktadır. Ona göre tarihçi, anlama gibi tarih bilimine özgü yöntemler kullanmalıdır.

Doğa bilimleri ile tarih bilimi ayrımı üzerinde duran Collingwood, tarih bilimi çalışmalarında uygulanmak üzere üç temel yöntem geliştirmiştir: Tarihsel imgelem, soru-yanit ve yeniden canlandirma. Tarihsel imgelem kuramı, tarihçinin geçmişe ilişkin bütünsel resmi nasıl yapacağ tarihçi, yetkelerin kendisine anlattığı noktaların arasında köprüler kurmalıdır. Tarihçi tarafından oluşturulan bu imgelem, tarihsel bağlamı vermesi açısından bir olmazsa olmazdır. Ancak, tarihçinin "kurduğu" bu resim, Collingwood'a göre bir edebiyatçının "kurgusundan" zorunlu olması bakımından farklıdır.

Collingwood'un soru ve yanit kuramında ise, tarihsel bir araştırmada metni anlaşılır kılacak tek yolun tarihçinin metnin yanıtladığı soruyu bulması oldugu sayıltısı temeldir. Soru ve yanıt mantığı, tarihsel araştırma ya da bilmenin felsefi bir sorgulamayla gerçekleşebileceğini savlayan bir tarih yöntemidir. Collingwood, yeniden canlandırma kuramında ise, geçmişteki bir düşüncenin aslına uygun olarak yeniden canlandırılmasının mümkün olduğu mutlak önkabulüyle yola çıkmıştır. Bu kurama göre, tarihçi, tarihsel eylemcinin düşüncesini "yeniden canlandırma" aracılığıyla zihninde aynı biçimde yeniden yaratabilmektedir.

Collingwood'un yeniden canlandırma kuramı ile onun her dönemin kendi tarihini yazabileceği fikri arasında bir çelişkinin olup olmadığı sorusu Collingwood'un tarih tasarımı ile ilgili en tartışmalı konu başlığını oluşturmaktadır. Collingwood, her dönemin kendi tarihini yazabileceği ve bu tarih yazımının da her dönem için yegâne olabilecek şey olduğu şeklindeki yaklaşımı birçok tarih felsefecisi tarafından eleştirilmiş, Collingwood'un "tarihin bir anlamı olmadığı öğretisi kadar tehlikeli anlamların sınırsızlığı kuramına yaklaştığı” görüşü sıkça ifade edilir olmuştur. Collingwood'un tarihte görelilik konusundaki bu iddialı görüşlerinin arkasında bazı noktalarda ciddi bir nesnellik kaygısı bulunmaktadır ki, çelişki gibi gözüken bu durum Collingwood'un da "çağının çocuğu olmasının" bir sonucudur. 


\section{Kaynakça}

Aysevener, K. (2001). Collingwood'un Tarih Felsefesi. Ankara: İmge.

Aysevener, K. ve Barutça, M. (2003). Tarih Felsefesi. İstanbul: Cem.

Bates, David. (1996). Rediscovering Collingwood's Spiritual History (In and Out of Context). History and Theory, 35 (1), 29-55.

Boucher, D. (1984). The Creation of the Past: British Idealism and Michael Oakeshott's Philosophy of History. History and Theory, 23 (2), 193-214.

Boucher, D. (1993). Human Conduct, History and Social Science in the Works of R. G. Collingwood and Michael Oakeshott. New Literary History, 24 (3), 697-717.

Boucher, D. (2000). Tocqueville, Collingwood, History and Extending the Moral Community. British Journal of Politics and International Relations, 2 (3), 326-351.

Boucher, D. (2003). Geçmişi Yaratmak - İngiliz İdealizmi ve Michael Oakeshott'in Tarih Felsefesi. Kubilay Aysevener ve E. Müge Barutça (Ed.), Tarih Felsefesi. içinde (s. 135-166), İstanbul: Cem.

Boucher, D. ve Vincent A. (2000). British Idealism and Political Theory. Edinburgh: Edinburgh University.

British Idealism Guide, Meaning, Facts, Information and Description, <http://www.e-paranoids.com/b/ br/british_idealism_1.html>. Erişim Tarihi: 25.01.2005.

Carr, E.H. (2002). Tarih Nedir?. Misket Gizem Gürtürk (Çev.). İstanbul: İletişim.

Collingwood, R. G. (1939). An Autobiography. Oxford: Oxford University.

Collingwood, R.G. (1996). Tarih Tasarımı. Kurtuluş Dinçer (Çev.). Ankara: Gündoğan.

Collingwood, R.G. (2001). Tarih Felsefesi Üzerine Denemeler. Erol Özvar (Çev.). İstanbul: Ayışı̆̆ı.

Doro, Giuseppina (2004). Re-Enactment and Radical Interpretation. History and Theory, 43 (2), 198-208.

Dray, W. H. (1980). Collingwood's Historical Individualism. Canadian Journal of Philosophy, 1 (1), 1-20.

Dray, W. H. (1995). History as Re-enactment - R. G. Collingwood's Idea of History. Oxford: Clarendon.
Evans, R.J. (1999). Tarihin Savunusu. Çev: Uygur Kocabaşoğlu. Ankara: İmge.

Goldstein, Leon J. (1970). Collingwood's Theory of Historical Knowing. History and Theory, 9 (1), 3-36.

Hopkins, Jasper (1965). Bultmann on Collingwood's Philosophy of History. The Harvard Theological Review, 58 (2), 227-233.

Hughes-Warrington, Marnie (2003). 'How Good an Historian Shall I Be?' - R. G. Collingwood, The Historical Imagination and Education. Exeter: Imprint Academic.

Inglis, Fred (2009). History Man - the Life of R. G. Collingwood. Princeton: Princeton University.

Jenkins, K. (1997). Tarihi Yeniden Düşünmek. Bahadır Sina Şener (Çev.). Ankara: Dost.

Johnson, Peter (1998). R. G. Collingwood - an Introduction. Bristol: Ray Monk.

Johnson, Peter (2013). Collingwood's The Idea of History. Norfolk: Bloomsbury Academic.

Kemp, Gary (2003). The Croce-Collingwood Theory as Theory. The Journal of Aesthetics and Art Criticism, 61 (2), 171-193.

Levesque, Stephane (2008). Thinking Historically Educating Students for the Twenty-First Century. Toronto: University of Toronto.

Mink, Louis O. (1964). Collingwood's Dialectic of History, History and Theory, 7 (1), 3-37.

Özlem, D. (1992). Tarih Felsefesi. İstanbul: Ara.

Pavo, Raymundo R. (2010). Between Collingwood's and Croce's Art-Theories: a Comparative Study. Kritike, 4 (1), 79-93.

Salas, Charles G. (1987). Collingwood's Historical Principles at Work. History and Theory, 26 (1), 53-71.

Strauss, Leo. (1952). On Collingwood's Philosophy of History. The Review of Metaphysics, 5 (4), 559-586.

Tosh, J. (1997). Tarihin Peşinde. Özden Arıkan (Çev.). İstanbul: Türkiye Ekonomik ve Toplumsal Tarih Vakfi.

Türk Dil Kurumu Türkçe Sözlük. (1998). 9. Baskı. Cilt: 1.

Van Der Dussen, Jan. (2012). History as a Science - the Philosohy of R. G. Collingwood. New York: Springer. 